\title{
Viipuri - kulttuurin kaupunki
}

Viipurin kulttuurihistorian tutkimus sekä sen päivittäminen osaksi uusinta tieteellistä keskustelua ja sen näkökulmia ovat Viipurin Suomalaisen Kirjallisuusseuran itselleen ottamia tehtäviä. Suomenkielisen kirjallisuuden kartuttamiseksi vuonna 1845 perustettu seura ehti toimia Viipurissa lähes sadan vuoden ajan. Jatkosodan jälkeen seuran kotipaikaksi vakiintui Helsinki ja sen tehtävätkin ovat uudistuneet. Kolme vuosikymmentä sotien jälkeen (1976) seura alkoi julkaista VSKS:n Toimitteita -nimistä tieteellistä sarjaa, jonka panivat alulle seuran viipurilaistaustaiset professorijäsenet. Sarjan 17 ensimmäisessä numerossa on julkaistu yli 150 tutkimusartikkelia, katsauksia, konferenssiesitelmiä ja joitain muistelmakirjoituksia sekä lähdeaineistoja.

Kun vuonna 2011 Viipuria käsittelevän tutkimuksen edistäminen vahvistettiin VSKS:n yhdeksi päätehtäväksi, päätettiin myös Toimite-sarjaa uudistaa niin, että numerosta 18 alkaen siinä julkaistaan pääasiassa vertaisarvioituja tutkimusartikkeleita. Toimitteista viisi (18-22) muodostavat kokonaisuuden Viipuri - kulttuurin kaupunki. Kunkin osan tehtävä on paikata kaupungin historiantutkimuksen aukkoja ja avata aiemmin tutkittuakin uusista näkökulmista. Kulttuuri ymmärretään tässä yhteisesti jaettujen ja sukupolvesta toiseen periytyvien arvojen, tapojen ja merkitysten kokonaisuudeksi, joihin korkeakulttuurin muodotkin luetaan.

Tulevista Toimitteista numerot 19-22 on suunniteltu etenemään kronologisesti ja sisältämään tutkimusartikkeleita Viipurin kulttuurihistoriasta. Osien aikajänteet seuraavat Karjalan ja tarkemmin läntisen Karjalankannaksen kulttuurihistorian periodisointia, joka poikkeaa muun Suomen historiallisesta aikakausijaottelusta. Ne käsittelevät varhaismodernia Ruotsin vallan aikaa (n. 1550-1710), Vanhan Suomen aikaa ja saksankielisen kulttuurikauden viime vaihetta autonomian ajan alkuvuosikymmeninä (n. 1710-1840) sekä sitä seurannutta ruotsin- ja suomenkielisen kulttuurin huipentumista (n. 1840-1940). Viimeisessä osassa käsitellään sekä talvi-ja jatkosodan jälkeisen ajan Suomen viipurilaista diasporaa että neuvostoliittolaista ja venäläistä Viipuria (n. 19402020). Teema-artikkelien avulla on tarkoitus luoda edellytyksiä synteesin rakentamiselle Suomen oloissa ainutlaatuisen kerrostuneen ja monikansallisen kaupunkikulttuurin historiasta.

Toimite 18, Muuttuvien tulkintojen Viipuri on tulevia osia valmisteleva katsaus Viipurin kulttuurihistoriaan ja tutkimustilanteeseen sekä uusien kysymyksen- 
asettelujen herättäjä. Se ei ole kronologisesti tai temaattisesti kattava, mutta siinä on tarjolla yleiskuvan aineksia ja eri kulttuurin osa-alueisiin uppoutuvia syväluotauksia. Henkisen kulttuurin keskeisistä osa-alueista esimerkiksi koulutus, uskonto ja kansanliikkeet sekä esineellisen osalta kaupunkiarkkitehtuuri ja muistomerkit jäävät varsin vähälle huomiolle, koska niitä tarkastellaan seikkaperäisesti sarjan tulevissa osissa.

Referee-prosessin läpikäyneet tutkimusartikkelit on merkitty Tieteellisten seurojen valtuuskunnan (TSV:n) myöntämällä vertaisarviointitunnuksella. Mukana on myös katsausartikkeleita, joissa niissäkin dokumentointi ja tutkimuskysymykset täyttävät yleiset tieteellisen kirjoittamisen periaatteet. Artikkeleissa esiintyvät venäjänkieliset henkilönimet ja nimekkeet on translitteroitu leipätekstissä kansallisen standardin mukaan. Tiedonhaun helpottamiseksi ne on kuitenkin merkitty bibliografiaan kansainvälisen ISO 9-standardin mukaisessa muodossa. Artikkelien painamaton lähdeaineisto ja sanomalehdet on merkitty kokonaisuudessaan loppuviitteisiin; sen sijaan muu julkaistu lähdeaineisto ja tutkimuskirjallisuus on koottu teoksen loppuun yhteiseen kirjallisuusluetteloon. Mainittakoon, että kokoelman artikkeleissa usein mainitusta Jacob Judénista käytetään virkamiehenä ja yksityishenkilönä ruotsinkielistä nimimuotoa, kun taas suomalaisen valistuskirjailijan roolissa hänestä kirjoitetaan Jaakko Juteinina.

Artikkeleiden aihepiiriä on esitelty yleisölle VSKS:n Helsingin yliopistossa järjestämässä luentosarjassa Rajakaupungin kulttuurielämää 150o-luvulta 20oo-luvulle ja syyskuussa 2015 järjestetyssä Viipuri-tutkimuksen päivässä, jonka esitelmien aiheena olivat VSKS:n fennomaanit ja heidän hankkeensa. Osan vastaavana toimittajana on Anu Koskivirta. Toimituskuntaan kuuluvat lisäksi sarjan päätoimittaja Pentti Paavolainen ja toimitussihteeri Sanna Supponen. Kuvatoimittaja Risto Marjomaa ansaitsee kiitoksen siinä missä artikkeleista arvokasta palautetta lausunnoissaan antaneet kollegat.

Helsingissä, 8. helmikuuta 2016

Pentti Paavolainen, Anu Koskivirta, Sanna Supponen 